Jurnal Kejuruteraan SI 1(4) 2018: 75-85

http://dx.doi.org/10.17576/jkukm-2018-si1(4)-10

\title{
Hydrophobic Nanosilica as Fluid Loss Control Additive for High Performance Water- Based Drilling Fluids
}

\author{
(Nanosilika Hidrofobik sebagai Aditif Kawalan Penyusutan Cecair bagi Cecair Pengeboran Berasaskan Air \\ Berprestasi Tinggi)

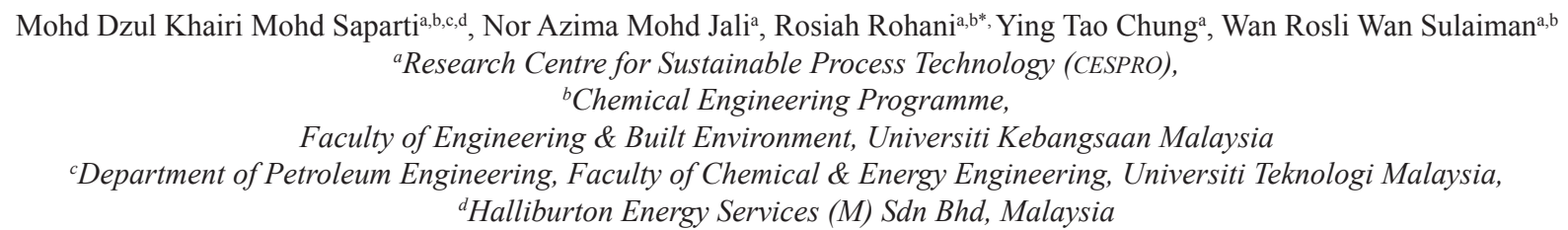

ABSTRACT

Water-based drilling fluids (WBDF) are widely applied in oil and gas industry due to its environmental compatibility. However, the issues regarding on the fluid loss control is still a major concern in drilling fluid industry. Therefore, the introduction of nanomaterials in drilling fluids is one of the advanced approaches to solve the problems. Nanomaterials possess inherent physico-chemical properties compared to micro or macro-sized particles due to its large surface area. In this study, nanosilica particles have been selected as fluid loss control additive due to its high stability and functionality. The nanosilica particles were synthesized via sol-gel technique and the average size obtained was $70 \pm 7 \mathrm{~nm}$. The nanosilica was then modified using Sodium Dodecyl Sulphate (SDS) in order to produce hydrophobic particles. It was done in order to produce hydrophobic layer that can prevent fluid inflow-outflow in order to stabilize the wellbore during drilling operation by producing a filtration layer on the wall of the wellbore which overcome the fluid loss. A ratio of $50 \mathrm{wt} \% \mathrm{SDS} / \mathrm{SiO}_{2}$ was used and the contact angle obtained was $100 \pm 8.13^{\circ}$. The hydrophobic nanosilica was added in the drilling fluid formulation and the performance was evaluated in terms of filter cake thickness and filtrate volume. The filter cake thickness was found less than $1 \mathrm{~mm}$ and the fluid loss reduction percentage was 44\% for drilling fluid with hydrophobic nanosilica. Besides, the drilling fluids with hydrophobic nanosilica presented a good rheological behaviour, thermal stability and a high methylene blue capacity while the filtrates exhibited low alkalinity, low chloride ion concentration and total hardness lower than $500 \mathrm{mg} / \mathrm{L}$.

Keywords: Drilling fluids; nanoparticles; water-based; hydrophobic; additives

ABSTRAK

Bendalir penggerudian berasaskan air (WBDF) digunakan secara meluas di dalam industri minyak dan gas kerana kesesuaiannya terhadap alam sekitar. Namun, masalah berkenaan kawalan kehilangan bendalir menjadi kebimbangan di dalam industri bendalir penggerudian. Oleh itu, zarah nano telah diperkenalkan dalam industri bendalir penggerudian untuk mengatasi masalah tersebut. Zarah nano mempunyai sifat kimia dan fizikal yang baik berbanding dengan zarah bersaiz mikro dan makro kerana permukaannya yang lebih luas. Dalam kajian ini, zarah nano silika telah dipilih sebagai bahan tambahan untuk kawalan kehilangan bendalir disebabkan kestabilan dan fungsinya. Zarah nano silika telah disintesis melalui teknik sol-gel dan purata saiz zarah yang diperoleh adalah $70 \pm 7 \mathrm{~nm}$. Kemudian, zarah nano silika ini diubah suai dengan Sodium Dodesil Sulfat (SDS) untuk memperoleh permukaan yang hidrofobik. Ini bertujuan untuk mengatasi aliran masuk-aliran keluar bendalir seterusnya menstabilkan lubang gerudi semasa operasi penggerudian dijalankan dengan menghasilkan lapisan turas pada dinding telaga gerudi untuk mencegah berlakunya kehilangan bendalir. Nisbah 50 wt\% $\mathrm{SDS} / \mathrm{SiO}_{2}$ telah digunakan dan sudut sentuhan yang diperoleh adalah $100 \pm 8.13^{\circ}$. Zarah nano silika yang bersifat hidrofobik telah ditambah dalam formulasi bendalir penggerudian dan prestasi bendalir penggerudian telah dinilai berdasarkan ketebalan kek turasan dan isi padu turasan. Ketebalan kek turasan adalah kurang daripada 1 mm dan peratus pengurangan kehilangan bendalir adalah sebanyak 44\% untuk bendalir penggerudian dengan zarah nano silika yang hidrofobik. Selain itu, bendalir penggerudian dengan zarah nano silika yang hidrofobik menunjukkan sifat reologi yang baik, kestabilan sifat terma dan kapasiti metilena biru yang tinggi manakala turasannya menunjukkan kealkalian yang rendah, kepekatan ion klorida yang rendah dan jumlah kekerasan yang kurang daripada $500 \mathrm{mg} / \mathrm{L}$.

Kata kunci: Bendalir penggerudian; zarah nano; berasaskan air; hidrofobik; bahan tambahan 


\section{INTRODUCTION}

Drilling fluid is one of the most important components for well construction in oil and gas industries which directly comes into contact with the wellbore during drilling operation process. Drilling fluid could be defined as a complex fluid mixture with a combination of solid suspension, mixture and emulsion of liquid used in operations to drill boreholes into the earth (Shah et al. 2010). The real basis of drilling fluid was initiated with the mixture of water and plastic materials as a drilling fluid to enhance the wellbore stability and strength. Drilling fluid can be classified into three main categories, i.e. water-based drilling fluid (WBDF), oil-based drilling fluid (OBDF) and gas-based drilling fluid (GBDF) (Apaleke et al. 2012). Among these drilling fluids, WBDF has gained widespread attention and are commonly utilized in drilling process, in considerations on the economic and environmental aspects, which is highly preferable for high temperature and high pressure (HTHP) drilling process (Abduo et al. 2016).

Drilling fluids yield multiple functions in a drilling process. For instance, the drilling fluids act as the stability support of the hole, lubricant and coolant to the drilling bits, as well as eliminate cuttings from borehole and prevent the fluids flow between borehole and the formation (Al-Yasiri \& Al-Sallami 2015). However, fluid loss is one of the problems in drilling process where excessive invasion into the formation and drilled cuttings may jeopardize stability of the borehole and surface drilled solids separation from the drilling fluids system itself. This phenomenon may possibly happen when drilling through a high permeability formation which resulted in thick filter cake, or drilling into a highly water intake lithology. Consequently, the filter cake formation with excessive thickness would lead to differential stuck pipe. Conventionally filter cake development in a wellbore is initiated and can be exploited through mechanical and chemical interactions. Recent research found that the filter cake formation can also be controlled by applying electric fields to the system (Ahmad \& Ibrahim 2002), however this approach is still debatable. The most common way to engineer cake formation is through controlled addition of additives into the drilling fluid, with the intention to improve the drilling performance by altering its characteristics and composition. Several additives with different functionalities which are utilized in the drilling process are available in the market such as shale inhibitor, fluid loss controller, viscosifier and weighing agent (Nwaoboli 2014). All these additives possess specific purposes in the drilling fluids, i.e. as $\mathrm{pH}$ controller, corrosion inhibitor, filtrate loss emulsifier and etc.

The employment of nanomaterials in drilling fluids has come to the forefront of research and appeared as practicable approaches in improving drilling process. Nanomaterials are equipped with magnificent physico-chemical properties and play a vital role in solving the technical and environmental issues in drilling operation such as wellbore instability, pipe sticking problem and lost circulation (Nabhani \& Emami 2012). Nanomaterials are engineered materials which are known to be outstanding and much effective compared to micro or macro-sized particles in conventional drilling fluids due to their fine nature and enormous surface area. The nanomaterials could be synthesized or tailor-made according to the specific requirements or functionalities of the drilling fluids (Abdo 2012). The promising aspect of nanomaterials in the formulation of high performance drilling fluid has high potential in overcoming the current challenges in drilling industry. There are various types of nanomaterials reported in literature for the purpose of enhancing drilling fluid performance (Vryzas \& Kelessidis 2017).

Recently, nanosilica has been selected as one of the potential nanomaterials to be added in the drilling fluid formulation owing to their stability, low toxicity and the functionality with a range of molecules and polymers (AZoNano 2013). Nanosilica can potentially act as nonreactive shale inhibitors and prevent water invasion by plugging the nano-size pores. In this way, the shale stability was enhanced and the shale swelling effect could be reduced (Alias et al. 2014). There are many techniques to synthesize nanosilica according to the required properties. One of the well-known and simplest methods is via sol-gel method. Several reactant parameters such as feed rate and temperature of the reactant, did impose significant effects on the particles size range to be obtained (Jafarzadeh et al. 2009). Besides, hydrophobicity of the nanomaterials is a major concern in drilling fluid formulation as the hydrophobic nature would prevent the fluid inflow-outflow and reduce fluid loss. Since the usual nanosilica particles are hydrophilic in nature, they should be modified to hydrophobic prior addition to the drilling fluid.

The main purpose of this study is to synthesize and characterize hydrophobic nanosilica as a fluid loss additive for water-based drilling fluid. The nanosilica was synthesized via sol-gel technique and the surface of nanosilica was further modified into hydrophobic characteristic using Sodium Dodecyl Sulphate (SDS). The drilling fluid performance was then compared between drilling fluid added with hydrophilic nanosilica and hydrophobic nanosilica. The filter cake produced after the filtration was further analyzed and the filtrate was also examined to detect the chemical composition based on a few characterization tests. By performing modification on the nanosilica nanoparticles, the drilling fluid performance was targeted to be improved in reducing the fluid loss which could further enhance the wellbore stability and strength that help in overcoming some of the technical problems in the drilling industry.

\section{EXPERIMENTAL}

MATERIALS

Drilling fluid formulation consisted of Bentonite, Barazan D Plus, Soda Ash, Caustic Soda, Barite, Clayseal Plus and potassium chloride $(\mathrm{KCl})$ were kindly supplied by Halliburton Energy Services (M) Sdn. Bhd. Tetraethyorthosilicate (TEOS, $99 \%$ purity), ethanol ( $99 \%$ purity) and ammonia solution were purchased from Sigma Aldrich Co., USA. Sodium Dodecyl 
Sulphate (SDS) was supplied by Merck Co., Germany. All chemicals were used as received.

\section{SYNTHESIS OF NANOSILICA}

The nanosilica particles were prepared by sol-gel method. There are two major reactions involved, i.e. hydrolysis and polymerization (condensation). Firstly, $5 \mathrm{ml}$ of TEOS was added to $30 \mathrm{ml}$ of ethanol in the conical flask at room temperature and were sonicated for $10 \mathrm{~min}$. After that, $1 \mathrm{ml}$ of distilled water was dropped into the reaction media with a feed rate of $0.2 \mathrm{ml} / \mathrm{min}$ to facilitate the hydrolysis of TEOS. After $20 \mathrm{~min}$, the ammonia solution which acted as a catalyst was fed into the reaction mixture at a feed rate of $0.01 \mathrm{ml} / \mathrm{min}$. The solution mixture was then sonicated for $1 \mathrm{hr}$. The gelation process was allowed for $1 \mathrm{hr}$. The gel was then centrifuged and washed with ethanol and distilled water. The samples were dried in oven for $24 \mathrm{hr}$ at $70^{\circ} \mathrm{C}$ and undergo calcination process at $600^{\circ} \mathrm{C}$ for $2 \mathrm{hr}$.

\section{MODIFICATION OF NANOSILICA SURFACE}

The nanosilica surface was further modified in order to obtain a hydrophobic surface. The material used for this modification process is Sodium Dodecyl Sulphate (SDS). The ratio of $\mathrm{SDS} / \mathrm{SiO}_{2}$ was set at $50 \mathrm{wt} \%$ based on literature (Qiao, Liang et al. 2016). Firstly, SDS was added into $150 \mathrm{ml}$ deionized water in a conical flask. The mixture was then stirred until all the SDS was dissolved. Next, $0.25 \mathrm{~g}$ of nanosilica was added into the mixture and stirred for $1 \mathrm{hr}$ prior to freeze-drying process for 3 days. After the drying process, the sample was heated in the furnace at temperature of $200^{\circ} \mathrm{C}$ for $30 \mathrm{~min}$. The samples were washed with ethanol to remove the unreacted SDS. Finally, the sample was dried in an oven for $12 \mathrm{hr}$ at $80^{\circ} \mathrm{C}$ prior usage.

\section{DRILLING FLUID FORMULATION AND FILTER CAKE FORMATION}

The drilling fluid samples were prepared according the following formulation and sequences:
i. Deionized water
ii. Salt $(\mathrm{KCl})$
iii. $\mathrm{pH}$ adjuster (Caustic soda)
iv. Viscosifier (Barazan D plus)
v. Shale inhibitor (Clayseal Plus)
vi. Weighing agent (Barite)
vii. Fluid loss additive (Hydrophobic nanosilica)

On the other hand, the filter cake was produced by using dead-end filtration system (Sterlitech HP4750, USA) with Novatexx 2413 as the filter (Freudenberg, Germany). The filtered area was a fixed $0.000146 \mathrm{~m}^{2}$ based on the size of the dead end filtration unit. Novatexx 2413 as per manufacturer's specifications are as follow: weight $100 \mathrm{~g} / \mathrm{m}^{2}$, air permeability at $200 \mathrm{~Pa}$ is $300 \mathrm{~L} / \mathrm{s}^{\mathrm{m}} \mathrm{m}^{2}$, and thickness of $0.19 \mathrm{~mm}$ at atmospheric condition. The filter cake formation was performed by preparing $200 \mathrm{ml}$ of drilling fluid samples containing nanosilica or without nanosilica for the filtration at different pressure of $80,100,120$ and 150 psi under the nitrogen flow. The volume of filtrate was then recorded after every 10, 20, and 30 mins and the thickness of filter cake was measured. All the filter cakes prepared were kept in desiccator for $24 \mathrm{hr}$.

TABLE 1. Drilling fluid formulation

\begin{tabular}{lc}
\hline Materials & Quantity \\
\hline Deionized water & Fill up until $200 \mathrm{ml}$ \\
Caustic soda & $0.06 \mathrm{~g}$ \\
Barazan D Plus & $1.14 \mathrm{~g}$ \\
Nanosilica & $0.25 \mathrm{~g}$ \\
$\mathrm{KCl}$ & $15.06 \mathrm{~g}$ \\
Clayseal Plus & $7 \mathrm{ml}$ \\
Barite & $40 \mathrm{~g}$ \\
\hline
\end{tabular}

Source: American Petroleum Institute, 2014

\section{CHARACTERIZATION}

NANOSILICA CHARACTERIZATION

The average particle size and distribution of nanosilica was measured using Zetasizer (Malvern, UK) and Transmission Electron Microscope (TEM; Philips, USA). These analyses were performed to confirm the nano size range of the synthesized nanosilica $(<100 \mathrm{~nm})$.

The synthesized nanosilica with or without modification were pelletized prior to the contact angle analysis. The contact angle could be measured by using contact angle meter (Kruss $\mathrm{GmbH}$, Germany) with Drop Shape Analysis software with accuracy of $+/-0.10^{\circ}$. The contact angle on the pellet samples would determine the hydrophilic or hydrophobic behaviour of the produced nanosilica.

CHARACTERIZATION ON DRILLING FLUID, FILTER CAKE AND FILTRATE

Fourier Transform Infrared Spectroscopy (FTIR) analysis was performed using Nicolet 6700 FTIR-ATR (Thermo Scientific, USA) to analyse the chemical properties and the functional groups of the filter cake samples. The samples were analysed with ranged wave between $600 \mathrm{~cm}^{-1}$ to $4000 \mathrm{~cm}^{-1}$ and scanned 10 times with scanning time of $1 \mathrm{~min}$.

The rheology analysis was performed by using Rheometer MCR500 (Anton Paar, Germany). An appopriate sample volume $(2 \mathrm{ml})$ was loaded onto the lower peltier of the rheometer before the rheometer was initiated. The rheometer was connected to the US200 software for further data analysis.

Field Emission Scanning Electron Microscope (FESEM) (Zeiss 55VP SUPRA, USA) was used to study the structural and morphological properties of the filter cake samples while Energy Disperse X-ray (EDX, ibSS, USA) was to determine the chemical elements or composition of the filter cake samples after the filtration with different types of drilling fluids.

Thermal Gravimetric Analysis (TGA) was used to analyse the thermal detection based on the decomposition of sample 
by using TGA analyser (PerkinElmer Pyris-1, USA). The samples were analysed using $\mathrm{N}_{2}$ gas at ambient temperature with a heating rate of $10^{\circ} \mathrm{C} \mathrm{m^{-1 }}$ and the temperature range between $25^{\circ} \mathrm{C}$ to $600^{\circ} \mathrm{C}$.

The methylene blue capacity was determined using titration method where the drilling fluid was mixed with deionized water, sulphuric acid and hydrogen peroxide. The methylene blue was added until the blue ring appeared on the filter paper and the volume of methylene blue used was recorded. This test was conducted to identify the quantity of reactive clay in the drilling fluid.

The alkalinity test of filtrate was conducted to determine the concentration of hydroxyl ion, carbonate ion and bicarbonate ion in the filtrate samples. This test was performed by using phenolphthalein and sulphuric acid. The volume of sulphuric acid used in titration based on the color change from yellow to pink was recorded as $\mathrm{Mf}$. The $\mathrm{M}_{\mathrm{f}}$ is relative filtrate alkalinity determined by amount of sulfuric acid used to lower down the filtrate $\mathrm{pH}$ to 4.3 . The $\mathrm{M}_{\mathrm{f}}$ value is to be compared to $\mathrm{P}_{\mathrm{f}}$ value to relatively determine soluble carbonate, bicarbonate and hydroxyl ions in the mud filtrate. This method can be applied in the low organic content mud system. Table 2 can be referred as a basis of ions computation.

TABLE 2: Ions Computation with $\mathrm{P}_{\mathrm{f}} / \mathrm{M}_{\mathrm{f}}$ Method

\begin{tabular}{lccc}
\hline $\begin{array}{l}\mathrm{P}_{\mathrm{f}} / \mathrm{M}_{\mathrm{f}} \\
\text { Relation }\end{array}$ & $\begin{array}{c}\text { Bicarbonate } \\
\left(\mathrm{mg} / \mathrm{HCO}_{3}{ }^{-}\right)\end{array}$ & $\begin{array}{c}\text { Carbonate } \\
\left(\mathrm{mg} / \mathrm{l} \mathrm{CO}_{3}{ }^{2-}\right)\end{array}$ & $\begin{array}{c}\text { Hydroxyl } \\
\left(\mathrm{mg} / 1 \mathrm{OH}^{-}\right)\end{array}$ \\
\hline $\mathrm{P}_{\mathrm{f}}=0$ & $1220 \times \mathrm{Mf}$ & 0 & 0 \\
$\mathrm{P}_{\mathrm{f}}=\mathrm{M}_{\mathrm{f}}$ & 0 & 0 & $340 \times \mathrm{Mf}$ \\
$2 \mathrm{P}_{\mathrm{f}}=\mathrm{M}_{\mathrm{f}}$ & 0 & $1200 \times \mathrm{Pf}$ & 0 \\
$2 \mathrm{P}_{\mathrm{f}}>\mathrm{M}_{\mathrm{f}}$ & 0 & $1200(\mathrm{Mf}-\mathrm{Pf})$ & $340(2 \mathrm{Pf}-\mathrm{Mf})$ \\
$2 \mathrm{P}_{\mathrm{f}}<\mathrm{M}_{\mathrm{f}}$ & $1220(\mathrm{Mf}-2 \mathrm{Pf})$ & $1200 \times \mathrm{Pf}$ & 0
\end{tabular}

Salinity test was done to determine the concentration of chloride ion contained in the drilling fluid filtrate. In this test, potassium chromate and silver nitrate were used as the reagents. The volume of silver nitrate used for the color change from yellow to red-brown was recorded.

The ions involved in the filtrate hardness (calcium/ magnesium ions) were determined by titration with a chelating agent, ethylenediaminetetraacetic acid (EDTA). EDTA was added in the solution until the color change from wine red to blue. The EDTA volume used was recorded.

\section{RESULTS AND DISCUSSION}

In this study, the effects of the nanosilica addition on the drilling fluid performance were discussed. The first section revealed on the properties of synthesized nanosilica and modified-nanosilica with SDS. The second section discussed on the drilling fluid performance in terms of filter cake thickness and filtrate volume with/without the addition of nanosilica while the last section was the characterization on different samples (drilling fluid, filter cake and filtrate).

\section{SYNTHESIS OF NANOSILICA}

In this study, the particles size of nanosilica produced was highly affected by several important parameters, i.e. the feed rate of ammonia, feed rate of water and reactant temperature. All these parameters were controlled as per mentioned in Sec. 2.2. The effects of each parameter on the particles size was listed in Table 3. Based on Table 3, the average particles size obtained for sample 4 was in nano range $(70 \pm 7 \mathrm{~nm})$. The findings indicated that the reactant temperature and feed flow rate should be controlled in order to ensure for smaller particles size. The findings obtained was in accordance with literature (Jafarzadeh et al. 2009). According to Stanley (2014) the parameters effects were related to agglomeration of particles during synthesis process. The average particles size and distribution for nanosilica sample 4 was further supported by zetasizer and TEM analyses as illustrated in Figure 1. This has further confirmed that the synthesis of nano-size silica could be performed with the water feed rate of $0.01 \mathrm{ml} / \mathrm{min}$, ammonia feed rate at $0.2 \mathrm{ml} / \mathrm{min}$, and reaction temperature ranging between 30 to $50^{\circ} \mathrm{C}$.

TABLE 3. Effect of parameters on particles size

\begin{tabular}{clc}
\hline Sample & \multicolumn{1}{c}{ Description } & $\begin{array}{c}\text { Average } \\
\text { Size }(\mathrm{nm})\end{array}$ \\
\hline 1 & $\begin{array}{l}\text { No control on reactant temperature } \\
\left(>50^{\circ} \mathrm{C}\right) \text { and feed rate }(>0.2 \mathrm{ml} / \mathrm{min})\end{array}$ & $627 \pm 9$ \\
2 & $\begin{array}{l}\text { Prolong the reaction time } \\
\text { Low calcination temperature } \\
\left(350^{\circ} \mathrm{C} \text { for } 2 \mathrm{hr}\right)\end{array}$ & $1050 \pm 12$ \\
& $\begin{array}{l}\text { Control the reactant temperature } \\
\left(30^{\circ} \mathrm{C}-50^{\circ} \mathrm{C}\right), \text { ammonia }(0.01 \mathrm{ml} / \mathrm{min})\end{array}$ & $70 \pm 7$ \\
& and water feed rate $(0.2 \mathrm{ml} / \mathrm{min})$ & \\
\hline
\end{tabular}

MODIFICATION OF NANOSILICA WITH SODIUM DODECYL SULPHATE

Since the nanosilica particles are expected to be in hydrophobic state as a fluid loss additive in drilling fluid, the modification of nanosilica surface was conducted in order to produce hydrophobic nanosilica. Contact angle analysis was used to evaluate the hydrophilic or hydrophobic behavior of the materials. The contact angle of nanosilica with/without modification was exhibited in Figure 2. According to Förch et al. (2009), the surface that has contact angle higher than $90^{\circ}$ was considered as hydrophobic surface (Fçrch et al. 2009). The modification was performed using SDS via thermal and drying technique. According to Qiao et al. (2016), the suitable ratio for the modification process was in the range of 0 to $75 \mathrm{wt} \%$. In this study, there were two SDS $/ \mathrm{SiO}_{2}$ ratio used to determine the contact angle difference, i.e. $20 \mathrm{wt} \%$ and $50 \mathrm{wt} \%$. Based on Figure 2, the contact angle obtained for modification with $20 \mathrm{wt} \% \mathrm{SDS} / \mathrm{SiO}_{2}$ was $91.6 \pm 3.32^{\circ}$ while $100 \pm 8.13^{\circ}$ with the ratio of $50 \mathrm{wt} \% \mathrm{sDS} / \mathrm{SiO}_{2}$. This finding has proven the increment of hydrophobicity with higher $\mathrm{SDS} / \mathrm{SiO}_{2}$ ratio, which were consistent with 
(i)

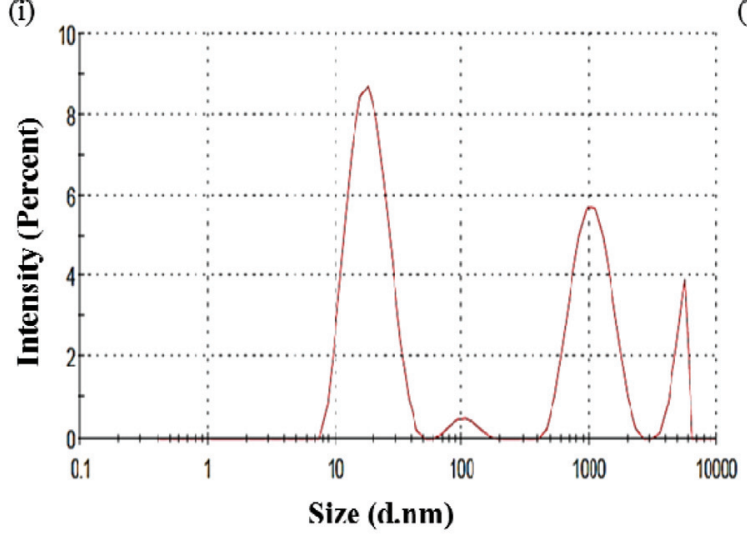

(ii)

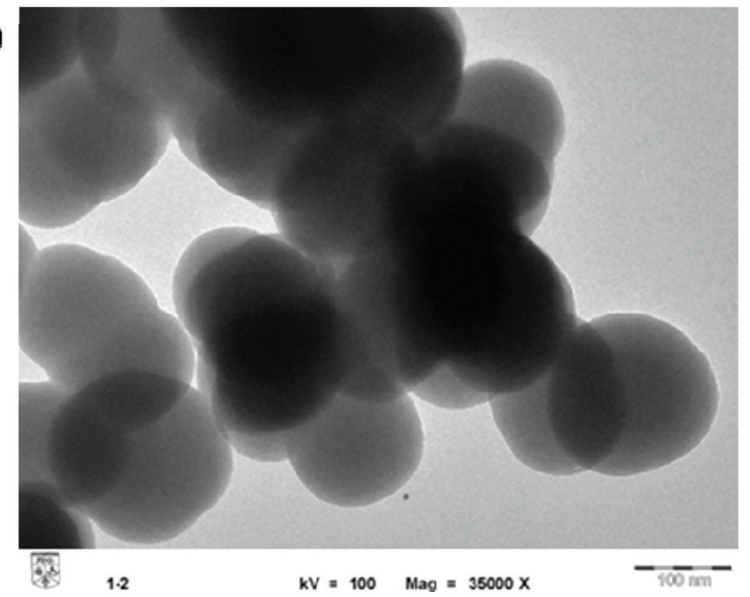

FIGURE 1. Particles size of nanosilica: (i) Zetasizer analysis (ii) TEM analysis

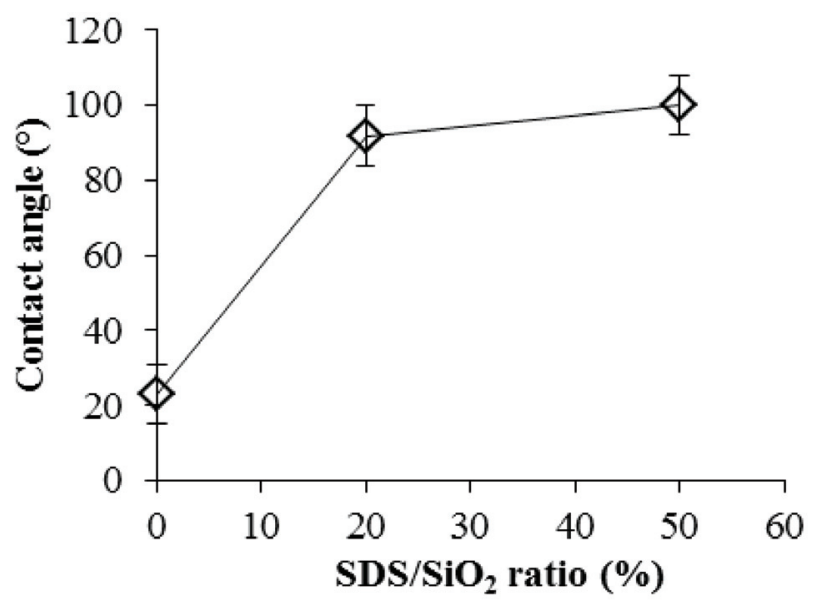

FIGURE 2. Contact angle of nanosilica with different $\mathrm{SDS} / \mathrm{SiO}_{2}$ ratio

(i) the findings in literature (Qiao et al. 2016). The obtained results were then compared with the nanosilica without any modification. As shown in Figure 3, the contact angle of the nanosilica before modification was $23 \pm 3.4^{\circ}$ which exhibited hydrophilic behavior while after modification with SDS was $100 \pm 8.13^{\circ}$ which was classified as hydrophobic. Hence, it could be concluded that the nanosilica was successfully modified into hydrophobic characteristic. Natural resources of hydrophobic in nature such as banana leaves are believed could be used as an alternative additives since their contact angle were reported above $130^{\circ}$ but the low melting temperature (around $80^{\circ} \mathrm{C}$ ) (Hassan, Ghazali et al. 2017) may hinder its application in drilling fluids.

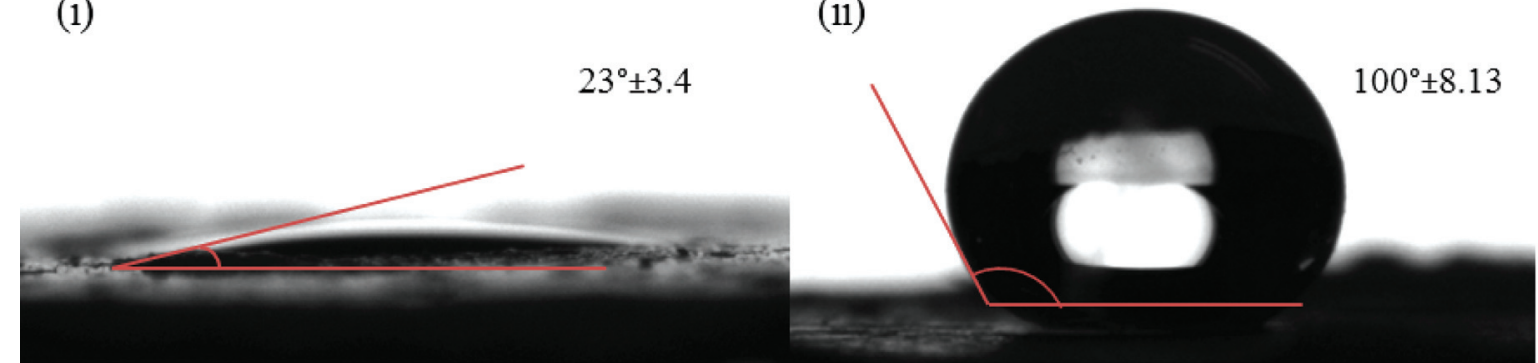

FIGURE 3. Contact angle of nanosilica: (i) without modification (ii) modification with SDS

\section{DRILLING FLUID PERFORMANCE}

The drilling fluid was prepared according to the formulation stated in American Petroleum Institute (API) 2014 and filtration was performed with a stirred cell system to produce the filter cake. The drilling fluid performance was evaluated in terms of filter cake thickness and filtrate volume. The performance of drilling fluid without any additives (DF + NS0) was then compared with drilling fluid added with fluid loss control additives: hydrophilic nanosilica (DF + NS1) and hydrophobic nanosilica (DF + NS2).

The first evaluation aspect of drilling fluid performance is filter cake layer thickness after filtration. The drilling fluid filtration process was performed at four different pressures, i.e. $80 \mathrm{psi}, 100 \mathrm{psi}, 120 \mathrm{psi}$ and $150 \mathrm{psi}$. The pressure range was used to simulate similar differential pressure in common wellbore condition during the drilling process. According to Figure 4, the drilling fluid without any fluid 
loss control additive presented the highest thickness of filter cake compared to the drilling fluid with hydrophilic and hydrophobic nanosilica. This was possibly due to the absence of pore-plugging particles or shale inhibitors which resulted in higher permeability allowing massive number of particles to accumulate on the surface of the filtered media. Higher pressure also led to the formation of thicker filter cake due to the higher influx flow rate. After the addition of either the hydrophilic or hydrophobic nanosilica, the filter cake thickness reduced gradually and became obvious at higher pressure ranges (120 and $150 \mathrm{psi}$ ). The findings indicate the effectiveness of nanosilica as a fluid loss control additive in drilling fluid. Furthermore, an increase in hydrophobicity of the nanosilica would prevent and/or reduce the fluid inflow and outflow in the wellbore. This finding become significant when simulating a static wellbore condition where further development of filter cake is significantly reduced, if not ceased, with addition of the hydrophobic nanosilica. Hence, the use of the hydrophobic nanosilica is superior in preventing the pipe sticking and shale swelling problems originated from the thickening of filter cake layers (Irfan 2016).

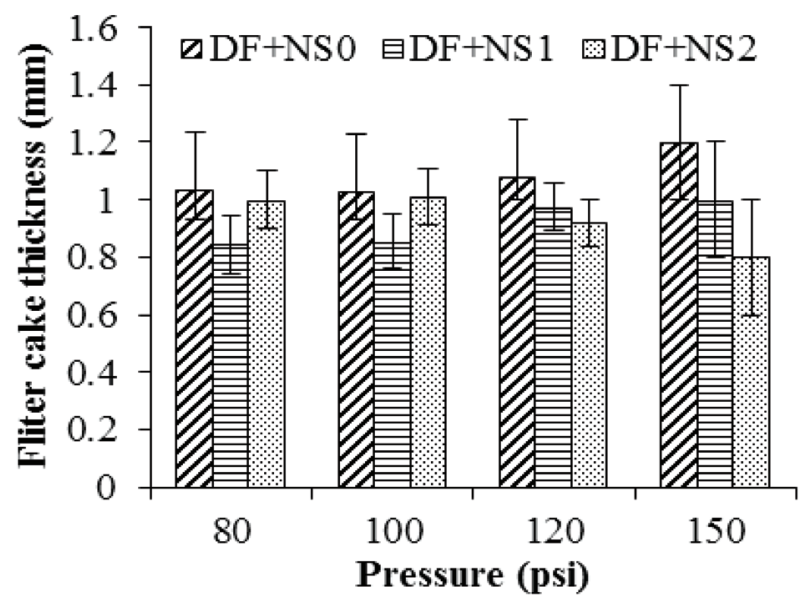

FIGURE 4. Thickness of filter cake for (i) DF + NS0 (ii) DF + NS1 (iii) $\mathrm{DF}+\mathrm{NS} 2$ at different pressure

The second evaluation aspect for the drilling fluid performance is filtrate volume. As shown in Figure 5, the filtrate volume obtained from different type of drilling fluid was recorded against time (up to $30 \mathrm{mins}$ ) at the pressure of 150 psi. Similarly to the findings of filter cake thickness, drilling fluid without any additive at a higher pressure demonstrated the highest filtrate volume. This was observed from the increase of fluid permeation rate that enhance the inflow and outflow of fluid at the wellbore. By introducing the hydrophilic and hydrophobic nanosilica particles into the drilling fluid, the filtrate volume reduced from $5.95 \mathrm{ml}$ to $4.48 \mathrm{ml}$ and $3.36 \mathrm{ml}$, respectively. The lower the filtrate volume, the lesser the fluid invasion into formation or drilled cuttings occurred in the drilling process. The fluid loss reduction percentage for drilling fluid was achieved at $25 \%$ and $44 \%$ with the respective hydrophilic and hydrophobic nanosilica. According to the study by Ragab and Noah

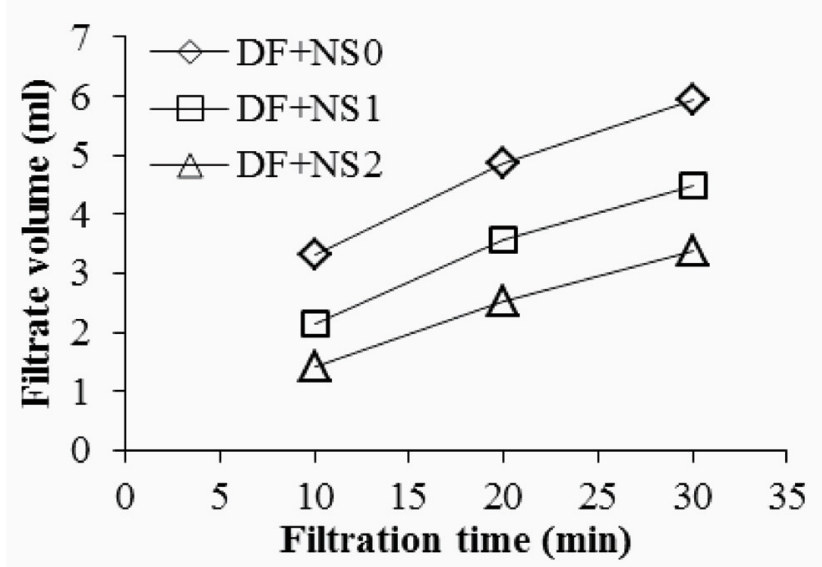

FIGURE 5. Filtrate volume for (i) DF + NS0 (ii) DF + NS1 (iii) DF + NS2 at 150 psi

(2014), the fluid loss reduction percentage was reported at $21 \%$ with the addition of nanosilica in the size range of 75 to $90 \mathrm{~nm}$ (similar with the synthesized hydrophilic nanosilica in this study) (Ragab \& Noah 2014). The result reported in the literature is considered comparable with the data presented by the synthesized hydrophilic nanosilica. The finding in this study is acceptable due to the achievement of high fluid loss reduction percentage with the employment of hydrophobic nanosilica. Therefore, it could be concluded that the hydrophobic nanosilica is an excellent fluid loss control additive (with thin filter cake and low filtrate volume) which demonstrates high potential in overcoming the technical issues in drilling process. Additionally, nanosilica also exhibited its exceptional properties as a fluid loss control additive in comparison to other additives reported in literature as shown in Table 4.

TABLE 4. Comparison of filter cake thickness with different nano additives

\begin{tabular}{lcc}
\hline Nano additives & $\begin{array}{c}\text { Filter cake thickness } \\
\left(\mathrm{mm} / \mathrm{m}^{2}\right)\end{array}$ & Study \\
\hline Clay & 804.15 & $\begin{array}{c}\text { (Zamir and Siddiqui } \\
\text { 2017) }\end{array}$ \\
$\begin{array}{l}\text { Rice husk } \\
\begin{array}{l}\text { i. Polyanionic } \\
\text { cellulose (PAC) }\end{array}\end{array}$ & 764.19 & (Okon, Udoh et al. \\
$\begin{array}{l}\text { ii. Carboxymethyl } \\
\text { cellulose (CMC) }\end{array}$ & 720.52 & $\begin{array}{c}\text { (Okon, Udoh et al. } \\
\text { 2014) }\end{array}$ \\
Nanosilica & 585.62 & This study \\
\hline
\end{tabular}

\section{CHARACTERIZATION}

The characterization performed on different samples, i.e. drilling fluid (with/without nanosilica), filter cake and filtrate were equally important in order to determine the effects of nanosilica addition towards the drilling fluid performance. 
DRILLING FLUID PROPERTIES

First, FTIR analysis was used to identify the functional groups contained in the drilling fluid. Table 5 lists the functional groups with wavenumbers for the FTIR spectra (Figure 6) for hydrophobic nanosilica, drilling fluid without additives, drilling fluid with hydrophilic nanosilica and drilling fluid with hydrophobic nanosilica. The FTIR for hydrophobic nanosilica particles showed the absorbance peak at 1095.9 and $806.2 \mathrm{~cm}^{-1}$ were assigned to $\mathrm{Si}-\mathrm{O}-\mathrm{Si}$ groups, while at $466.6 \mathrm{~cm}^{-1}$ was for the bending vibration of Si-O-Si bond. The deforming vibration of C-H were not found in the spectrum of the pure silica particles, indicating that SDS was successfully grafted onto the silica surface.

TABLE 5. Summary of peaks from FTIR spectra for drilling fluids: DF + NS0, DF + NS1 and DF + NS2 (Qiao et. al. 2016)

\begin{tabular}{lcc}
\hline Sample & $\begin{array}{c}\text { Functional } \\
\text { Group }\end{array}$ & $\begin{array}{c}\text { Wavenumber } \\
\left(\mathrm{cm}^{-1}\right)\end{array}$ \\
\hline Hydrophilic Nanosilica & Si-O-Si & $\begin{array}{c}1095.9,806.2, \\
466.6\end{array}$ \\
DF without additive & & \\
(DS+NS0) & $-\mathrm{OH}$ & 3404.3 \\
& $\mathrm{C}=\mathrm{C}$ & 1642.4 \\
& $\mathrm{C}-\mathrm{H}$ & 698.3 \\
DF with hydrophilic nanosilica & & \\
(DS+NS1) & $-\mathrm{OH}$ & 3404.1 \\
& $\mathrm{C}=\mathrm{C}$ & 1643.6 \\
& $\mathrm{C}-\mathrm{H}$ & 678.0 \\
DF with hydrophobic nanosilica & & \\
(DS+NS2) & $-\mathrm{OH}$ & 3404.9 \\
& $\mathrm{C}=\mathrm{C}$ & 1644.5 \\
& $\mathrm{C}-\mathrm{H}$ & 688.4 \\
\hline
\end{tabular}

On the other hand, the FTIR spectra for all the drilling fluids were showing the similar functional groups with a slight difference in the wavenumbers band-shifting. The hydroxyl group presence on the surface of the filter cakes were detected at the broad band of wavenumber ranging from 3404.1 to $3404.9 \mathrm{~cm}^{-1}$. Alkene groups were identified at 1642.4 to $1644.5 \mathrm{~cm}^{-1}$ and C-H was spotted at 678 to $698.3 \mathrm{~cm}^{-1}$. The addition of hydrophilic or hydrophobic nanosilica has slightly shifted the wavenumbers to a lower value in comparison to the original drilling fluid. Due to very low concentration of nanosilica added to the drilling fluids, the peaks between 1095.9 to $466.6 \mathrm{~cm}^{-1}$ that were assigned to nanosilica initially found in Figure 6(a) were not seen in Figure $6(b)-(d)$.

Rheological analysis is important in order to determine the rheological behavior of the drilling fluid samples, for instance, pseudoplastic, Bingham, Newton, or viscoplastic. Drilling fluids are similar with non-newton fluids which do not show constant viscosity at different shear rates. Thus, there is no direct proportionality between shear rate and shear stress. If the viscosity increase as shear rate increase, the non-Newtonian fluids are termed as dilatants (shear thickening) and if it reduces, they are called pseudoplastic (shear thinning) (Irfan 2016). Based on the results of rheology study, both drilling fluid without fluid loss additive and with

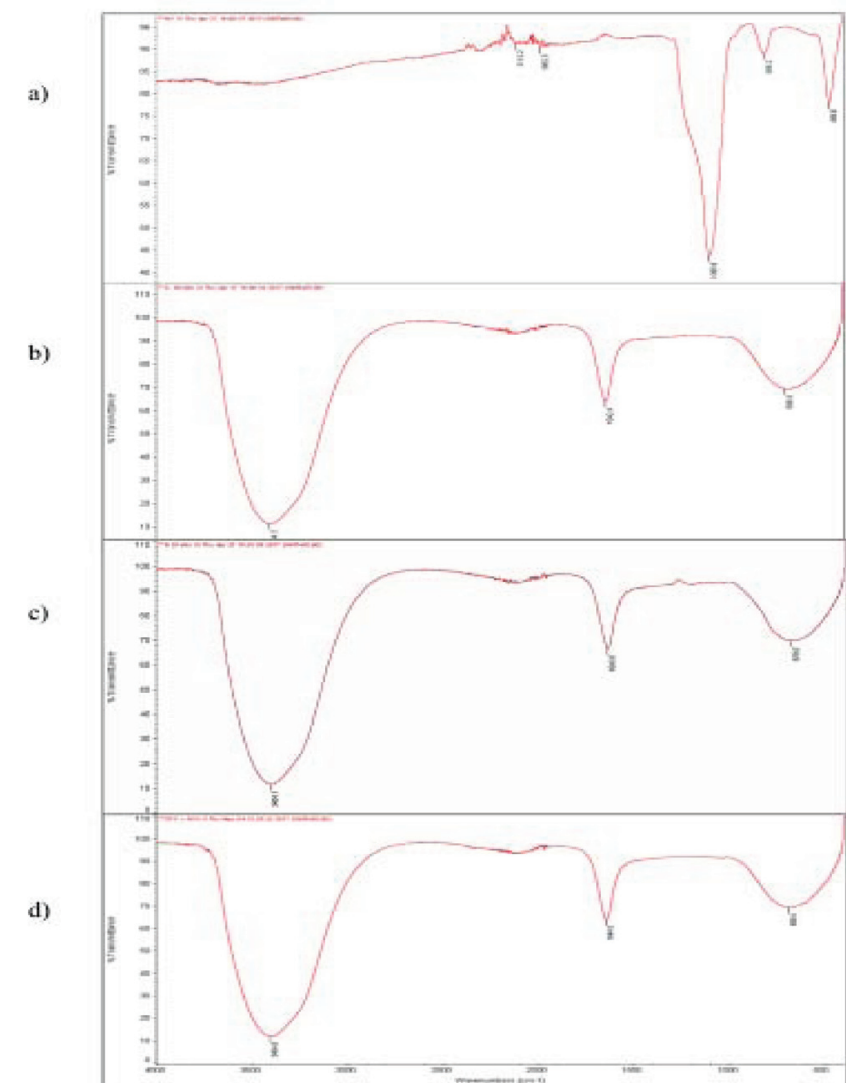

FIGURE 6: FTIR spectra of a) hydrophobic nanosilica, and (b) to (d) are the spectra of the filter cakes from b) DF without nanosilica-NS0, c) DF with hydrophilic nanosilica-NS1, d) DF with hydrophobic nanosilica-NS2

hydrophobic nanosilica samples show that the flow of fluid more to the pseudoplastic behavior because the viscosity is decreasing as the shear rate increased. Furthermore, there are few rheological models that indicate the fluids behavior. According to the result, the fluid behavior exhibited HerschelBulkley model characteristic. Figure 7 shows the rheological analysis and flow behavior of the drilling fluid without additives and with hydrophobic nanosilica. The viscosity of the samples presented a good trending, in which it would become constant at higher shear rates regime. Besides, at the Y-intersection which represents $\tau$ exhibited reading of around $10 \mathrm{~Pa}$. These is a good rheological readings as the viscosity of the drilling fluid could be maintained over various shear rate regime in drilling operation and maintained proper solids suspension in static condition.

\section{FILTER CAKE CHARACTERIZATION}

TGA analysis was conducted on the filter cake samples to evaluate the thermal effects on the decomposition of filter cake samples. Figure 8 presents the TGA analysis of filter cakes from drilling fluid without additives and with hydrophobic nanosilica. Based on the results, the first peak showed that the evaporation process occurred on the filter cake at about $50^{\circ} \mathrm{C}$. This weight loss indicated the decomposition of Barazan D Plus and further reduction of barite from filter 


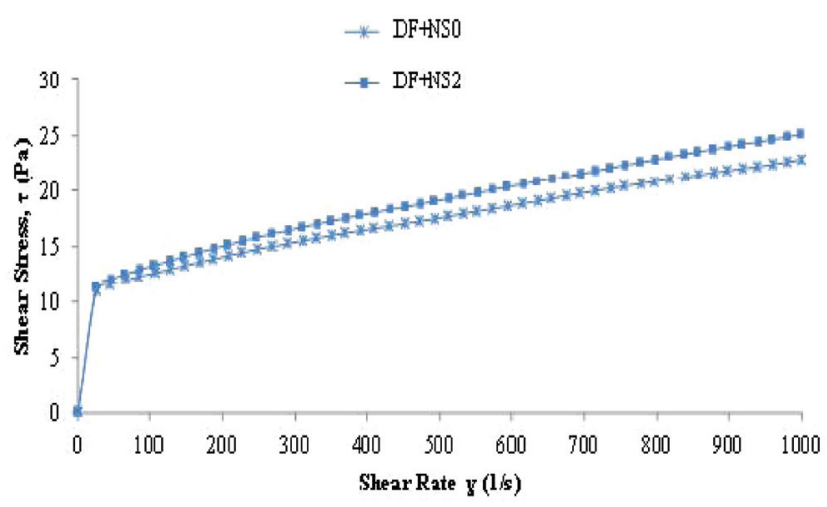

FIGURE 7. Rheology analysis for drilling fluid without additives (DF + NS0) and drilling fluid with hydrophobic nanosilica (DF + NS2) after nanosilica modification

cake component, which was the largest amount used in the formulation. The decomposition temperature of filter cake samples without any additives started at $60^{\circ} \mathrm{C}$ while filter cake samples with hydrophobic nanosilica decomposed at a higher temperature, which was after $200^{\circ} \mathrm{C}$. Besides, the weight loss occurred in range of temperature between $430^{\circ} \mathrm{C}$ to $600^{\circ} \mathrm{C}$ showed the dehydration process of clay mineral such as aluminium silicate that existed as a part of barite impurity. Thus, it could be concluded that drilling fluid which contained hydrophobic nanosilica could sustain a higher temperature before decomposition occurred.

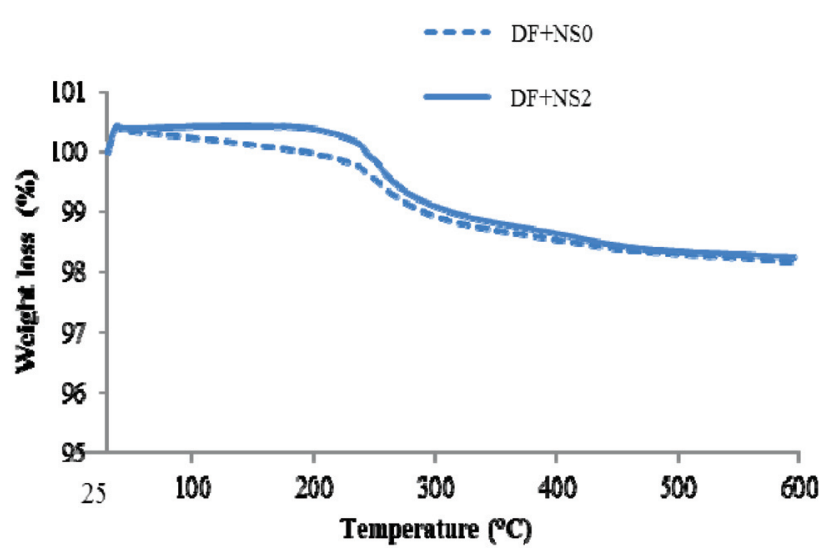

FIGURE 8. TGA analysis for drilling fluid without additives $(\mathrm{DF}+\mathrm{NS} 0)$ and drilling fluid with hydrophobic nanosilica $(\mathrm{DF}+\mathrm{NS} 2)$

The filter cake produced after the filtration process with different drilling fluids were characterized in terms of morphological properties based on FESEM and EDX to determine the elements existence in the filter cake layer. Figure 9 illustrates the FESEM surface images and EDX analysis for the filter cake obtained from drilling fluid without additives, with hydrophilic and hydrophobic nanosilica. As shown in Figure 9 (a)(i), the surface of the filter cake without any additive presented flatter layer which was not fully covered. Meanwhile, the filter cake layer for drilling fluid with nanosilica had fully covered the surface and there was slight agglomeration for the filter cake obtained for hydrophobic nanosilica-drilling fluid.

On the other hand, the EDX findings showed a higher percentage of $\mathrm{Ba}$ (Barite) with other elements such as $\mathrm{C}, \mathrm{O}$, $\mathrm{K}$ and $\mathrm{Cl}$ for the filter cake without any additives. This was possibly due to the absence of additives to cover the barite surface. Besides, the detection of Si element was found for the filter cake with the addition of hydrophilic and hydrophobic nanosilica. The percentage of Si was relatively low, likely due to the little amount of nanosilica $(0.25 \mathrm{~g})$ added into the drilling fluid formulation. The percentage of Ba was found reducing gradually due to the coverage by the nanosilica additives, which resulted in lesser Ba exposure. One would realize the significant swing in component percentage in the surface of filter cake when comparing between hydrophilic and hydrophobic nanosilica. Existence of high percentage of $\mathrm{Cl}$ and $\mathrm{K}$ suggested a preferable filter cake component. This switching is most likely due to the hydrophobic effect of the modified nanosilica which motivated accumulation of $\mathrm{Cl}$ and $\mathrm{K}$ whilst reducing $\mathrm{Ba}$ percentage on the filter cake surface.

\section{DRILLING FLUID AND FILTRATE CHARACTERIZATION}

In order to further confirm the efficiency of the drilling fluids, several characterization tests were performed on the filtrate obtained after filtration. The characterization tests were targeted to determine the filtrate alkalinities, chloride ion presence and the total hardness of the filtrate.

Methylene blue test (MBT) was conducted to identify the amount of reactive clay (bentonite) in the drilling fluid. The capacity of methylene blue is an estimation of total cation exchange capacity in drilling fluid. The test is to determine the capacity of methylene blue clay to adsorb the negative ions in clay. Hydrogen peroxide is a pretreatment added to remove the effects of organic materials such as lignosulfonates, lignite, cellulose polymer, polyacrylate and etc. Typically, the test is reported in terms of the reactive clay concentration in pounds per barrel. Based on the Figure 10, the capacity of MBT for drilling fluid without additives was $0.14 \mathrm{~kg} / \mathrm{m}^{3}$ while $1.71 \mathrm{~kg} / \mathrm{m}^{3}$ and $1.85 \mathrm{~kg} / \mathrm{m}^{3}$ for drilling fluid with hydrophilic and hydrophobic nanosilica, respectively. Fluid with hydrophobic nanosilica gives the highest value that described the high content of reactive clay in the fluid. The higher the MBT value, the higher the concentration of the drill solid in the drilling fluid. A good drilling condition should have MBT value less than $15 \mathrm{lb} / \mathrm{barrel}$ which is equivalent to $42.8 \mathrm{~kg} / \mathrm{m}^{3}$. In this study, the capacity of MBT for the drilling fluid with hydrophobic nanosilica was acceptable as it is less than $15 \mathrm{lb} /$ barrel.

Filtration alkalinity test was performed to identify the buffering capacity of the drilling fluid (capacity to neutralize acidic components). The concentration of hydroxide $\left(\mathrm{OH}^{-}\right)$, carbonate $\left(\mathrm{CO}_{3}^{2}\right)$ and bicarbonate $\left(\mathrm{HCO}^{-}\right)$ions present in the filtrates were determined. Based on Figure 11, the concentration of the $\mathrm{OH}^{-}$ions was $0 \mathrm{mg} / \mathrm{L}$ for all types of filtrate. The concentration of $\mathrm{CO}_{3}{ }^{2-}$ was relatively low for 
(a)

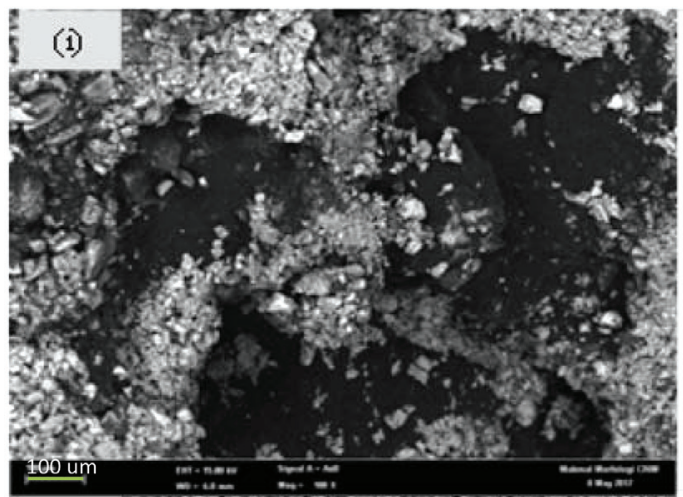

(b)

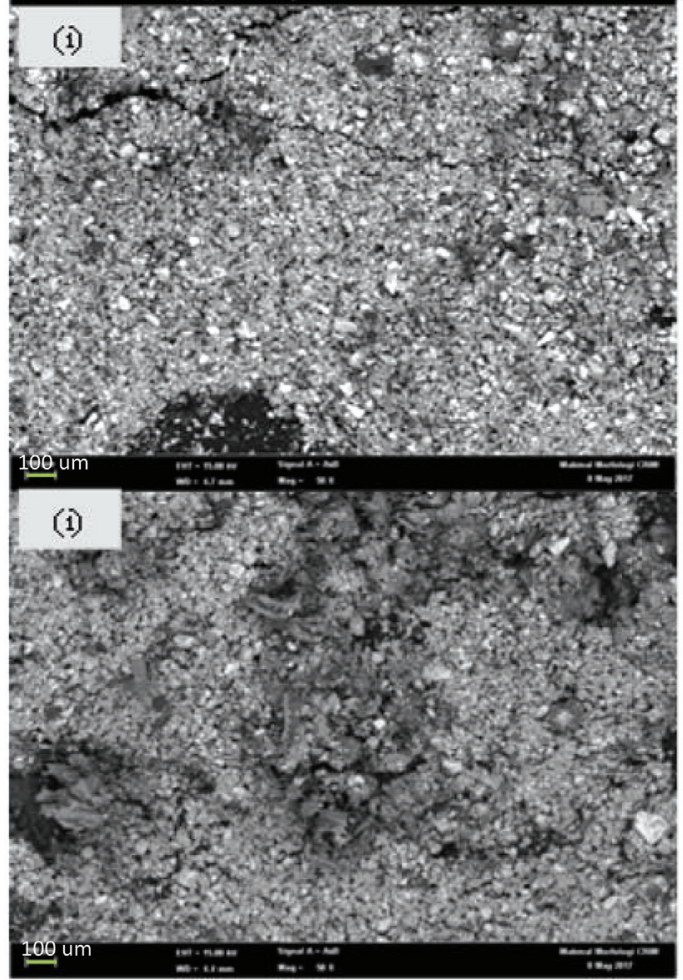

(ii)

$$
\sim \mathrm{Ba} \therefore \mathrm{C} \approx \mathrm{O} \text { 明 } \mathrm{K} \equiv \mathrm{C} 1
$$

39.5

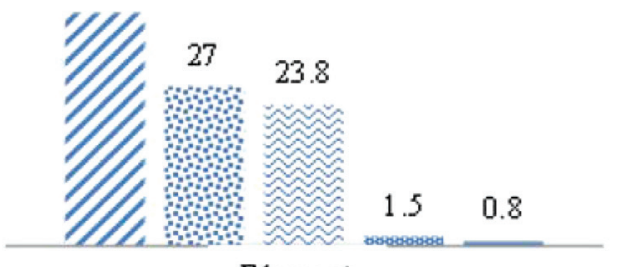

Element

(ii) $\quad \mathrm{Ba}: \mathrm{C} \approx \mathrm{O}: \mathrm{Si}$ 㽗 $\mathrm{K}=\mathrm{C} 1$

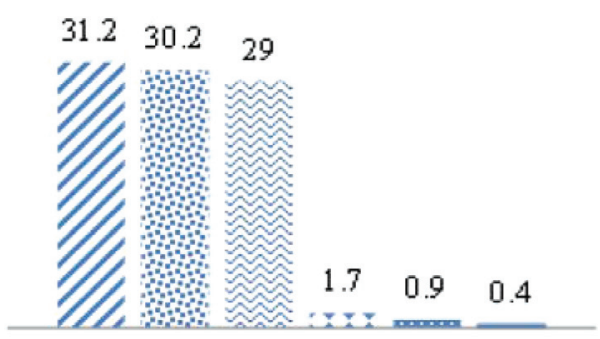

Element

(ii) $\boxplus \mathrm{C} 1<\mathrm{K} \approx \mathrm{O} \because \mathrm{Ba} \bullet \mathrm{Si}$

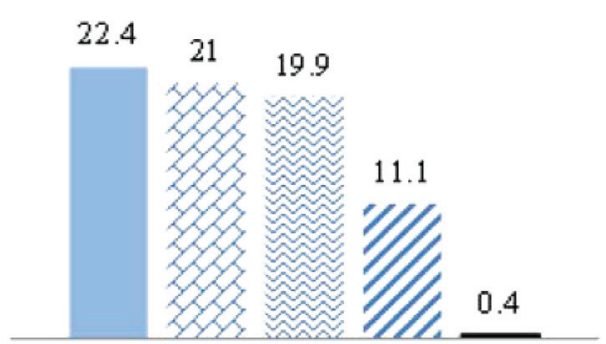

Element

FIGURE 9. Filter cake analysis: (i) FESEM (ii) EDX for (a) DF + NS0- no nanosilica addition (b) DF + NS1-with hydrophilic nanosilica addition (c) DF + NS2-with hydrophobic nanosilica addition

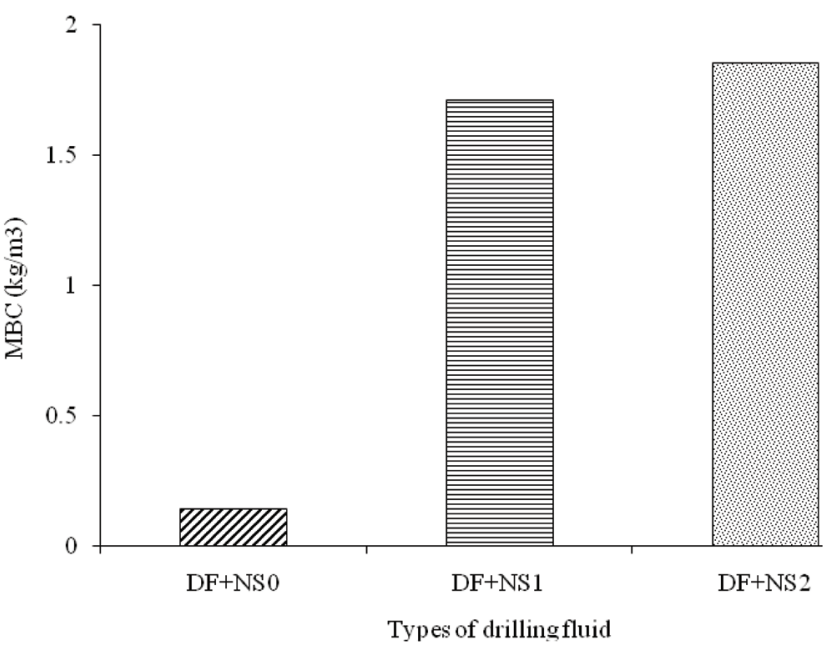

FIGURE 10. Methylene blue capacity in drilling fluids: DF + NS0no nanosilica addition, DF + NS1-with hydrophilic nanosilica addition and DF + NS2-with hydrophobic nanosilica addition

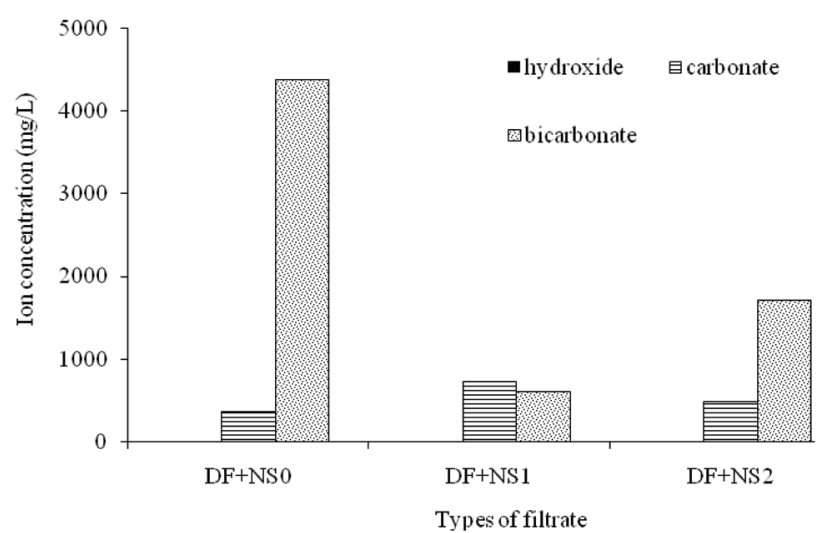

FIGURE 11. Concentration of $\left(\mathrm{OH}^{-}\right),\left(\mathrm{CO}_{3}{ }^{2-}\right)$ and $\left(\mathrm{HCO}^{-}\right)$ions in filtrates from DF + NS0-no nanosilica addition, DF + NS1-with hydrophilic nanosilica addition and DF + NS2-with hydrophobic nanosilica addition 
the 3 types of filtrate, i.e. $360 \mathrm{mg} / \mathrm{L}, 720 \mathrm{mg} / \mathrm{L}$ and $480 \mathrm{mg} / \mathrm{L}$, respectively for $\mathrm{DF}+\mathrm{NS} 0, \mathrm{DF}+\mathrm{NS} 1$ and $\mathrm{DF}+\mathrm{NS} 2$. The $\mathrm{HCO}-$ ion was found with the highest value of $4392 \mathrm{mg} / \mathrm{L}$ for DF $+\mathrm{NS} 0$. From the total soluble hydroxide, carbonate and bicarbonate ions in the three samples, it was found that filtrate without additives have the highest content of soluble ions followed by filtrates with nanosilica. Alkalinity arising from hydroxyl ions is generally accepted as beneficial while alkalinity resulting from carbonate or bicarbonate can affect the performance of the drilling fluid. Carbonate ions can be converted to different forms by changing the $\mathrm{pH}$ of the fluid.

Furthermore, the chloride ion content test was conducted for the three types of filtrate to identify the salinity of the filtrate produced. The filtrate is titrated with either $0.0282 \mathrm{~N}$ $\mathrm{AgNO}_{3}$ (silver nitrate) and are reported in the concentrations of chloride $(\mathrm{cCl}) . \mathrm{cCl}$ can be converted to the concentration of sodium chloride $(\mathrm{cNaCl})$ by multiplying 1.65 , or calcium chloride $\left(\mathrm{caCl}_{2}\right)$ by a factor of 1.57 . Figure 12 shows the chloride ion content in each filtrate sample. Based on the findings, the highest $\mathrm{Cl}, \mathrm{NaCl}, \mathrm{CaCl}_{2}$ concentrations were recorded by the filtrate sample without any additives. The high salinity of samples could reduce the degree of hydration of the drilling fluid. The degree of hydration reduced was possibly caused by the increase of flocculation rate (Nwaoboli 2014).

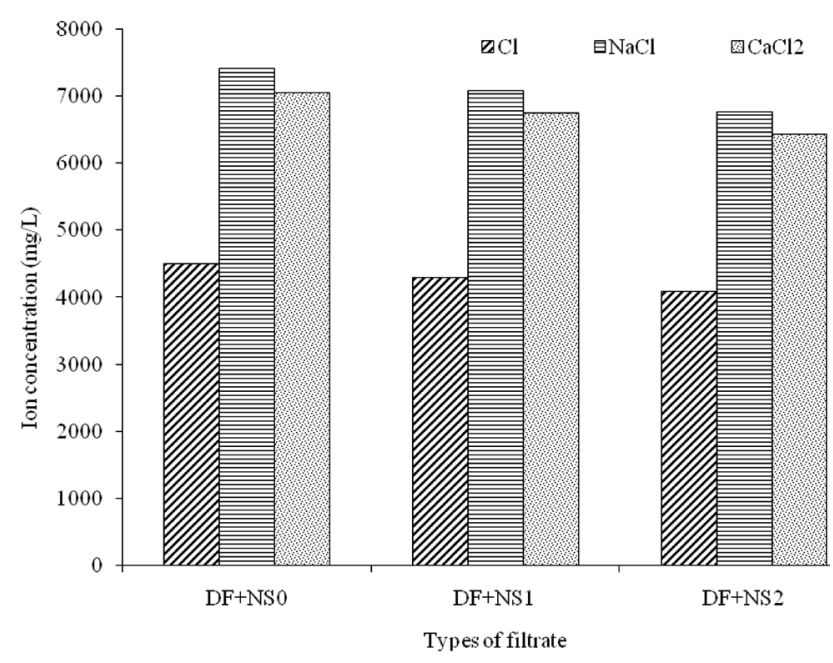

FIGURE 12. Content of chloride ion for different filtrates from $\mathrm{DF}+\mathrm{NS} 0$ - no nanosilica addition, DF + NS1-with hydrophilic nanosilica addition and DF + NS2-with hydrophobic nanosilica addition

The total hardness of filtrate was generally caused by the presence of calcium and magnesium. Thus, the total hardness test was used to identify the existence of calcium and magnesium ions $\left(\mathrm{Ca}^{2+}+\mathrm{Mg}^{2+}\right)$ in the filtrates. Figure 12 shows the total hardness of each filtrate sample. The filtrate with hydrophobic nanosilica presented the highest value of total hardness compared to other filtrates. According to Drilling Formulas (2016), the value of hardness should be lower than $500 \mathrm{mg} / \mathrm{L}$ to be acceptable in drilling operation.
Since the value was $480 \mathrm{mg} / \mathrm{L}$, it was still in an acceptable range but the value was relatively high for further process. Therefore, further treatment was needed such as using soda ash or caustic soda to remove the $\mathrm{Ca}$ and $\mathrm{Mg}$ ions in order to reduce the hardness in the samples. Reduction of total hardness can help chemicals to function, especially bentonite clay and improve the efficiency of most polymers.

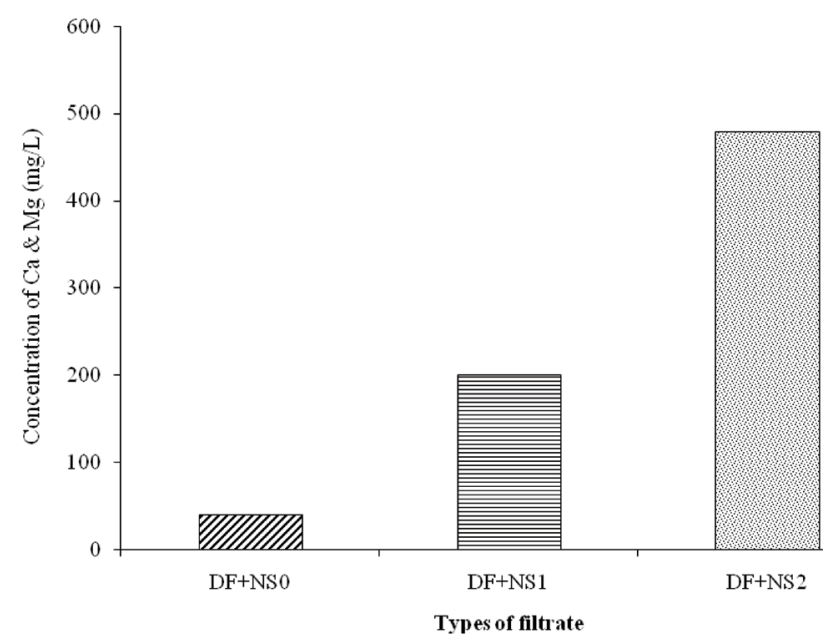

FIGURE 13. Total hardness for different filtrates from DF + NS0- no nanosilica addition, DF + NS1-with hydrophilic nanosilica addition and DF + NS2-with hydrophobic nanosilica addition

\section{CONCLUSION}

The synthesis and characterization of hydrophobic nanosilica as a fluid loss control additive in water-based drilling fluid was successfully investigated in this study. The synthesized hydrophilic and hydrophobic nanosilica particles were added to the drilling fluid formulation. The drilling fluid performance was then evaluated in terms of filter cake thickness and filtrate volume. The formulated drilling fluid samples, filter cake and filtrate samples were further analyzed and characterized. The observations and the major findings of this study could be concluded as following:

1. The nanosilica particles were produced via sol-gel method and the average particles size was around $70 \pm 7 \mathrm{~nm}$ with a low contact angle of $23 \pm 3.4^{\circ}$.

2. The modification of nanosilica into hydrophobic characteristic was performed with SDS at the ratio of $50 \%$ $\mathrm{SDS} / \mathrm{SiO}_{2}$. This ratio was selected due to the high contact angle value obtained, which was $100 \pm 8.13^{\circ}$.

3. The drilling fluid with the addition of the hydrophobic nanosilica demonstrated the thinnest filter cake and least volume of filtrate. The fluid loss reduction percentage for drilling fluid was estimated at $25 \%$ and $44 \%$ with hydrophilic and hydrophobic nanosilica. This has proven the low permeability of the drilling fluid with hydrophobic nanosilica which contributed to the fluid loss control. 
4. The drilling fluid added with hydrophobic nanosilica possessed better chemical and physical properties as fluid loss control additive. Besides, it showed the highest value for methylene blue capacity, lower value of alkalinity, lower chloride ion concentration and the total hardness of less than $500 \mathrm{mg} / \mathrm{L}$.

\section{ACKNOWLEDGEMENT}

The authors gratefully thank the Chemical Engineering Program, Faculty of Engineering and Built Environment of UKM, GUP/086/2016 research grant for supporting this research and Halliburton Energy Services for supplying the drilling fluids chemicals.

\section{REFERENCES}

Abdo, J. 2012. Nano-Enhanced drilling fluids: pioneering approach to overcome uncompromising drilling problems. Journal of Energy Resources Technology 134: 1-7.

Abduo, M. I., Dahab, A.S., Abuseda, H., Abdulaziz, A.M. \& Elhossieny, M.S. 2016. Comparative study of using water-based mud containing multiwall carbon nanotubes versus oil-based mud in HPHT fields. Egyptian Journal of Petroleum 25: 459-464.

Ahmad, A. L. \& Ibrahim, N. 2002. Pulsed electrophoretic membrane cleaning for dead-end ultrafiltration process. Jurnal Kejuruteraan 14: 3-16.

Al-Yasiri, M. S. \& Al-Sallami, W. T. 2015. How the drilling fluids can be made more efficient by using nanomaterials. American Journal of Nano Research and Applications 3: 41-45.

Alias, N., Tahir, N.F.M, Mohd, T.A.T., Ghazali, N.A., Yahya, E., Shahruddin, M.Z. Ramlee, N.A. \& Azizi, A. 2014. Rheological study of nanosilica based drilling fluid Applied Mechanics and Materials 575: 128-133.

Apaleke, A. S., Al-Majed, A. \& Hossain, M.E. 2012. State of the art and future trend general types of drilling fluid. SPE Drilling Fluid 1-13.

Azonano, 2013. Silicon Dioxide, Silica $\left(\mathrm{SiO}_{2}\right)$ Nanoparticles - Properties, Applications. https://www.azonano.com/ article.aspx? ArticleID $=3398$

Förch, R., Schönherr, H. \& Jenkins, A.T.A. 2009. Surface Design: Applications in Bioscience and Nanotechnology. WILEY-VCH Verlag GmbH \& Co. KGaA, Weinheim, Germany.

Hassan, H. A., Ghazali, M.J., Zainuddin, N.M. \& Azhari, C.H. 2017. Wax effect on hydrophobic properties of banana leaves. Jurnal Kejuruteraan 29: 1-7.

Irfan, Y. 2016. Study of viscosity and friction factor of nano drilling fluids along with torque and drag reduction. Master Thesis, Department of Petroleum Engineering University of Stavanger, Norway, Master of Engineering, 128.
Jafarzadeh, M., Rahman, I.A. \& Sipaut, C.S. 2009. Synthesis of silica nanoparticles by modified sol-gel process: The effect of mixing modes of the reactants and drying techniques. Journal of Sol-Gel Science and Technology 50: 328-336.

Nabhani, N. \& Emami, M. 2012. The potential impact of nanomaterials in oil drilling industry. Nanocon: 23-26.

Nwaoboli, A. 2014. Investigation of additives on drilling mud performance with " tønder geothermal drilling " as a case study. Master Thesis, Department of Chemical Engineering, Aalborg University, Denmark, Master of Science, 128.

Okon, A.N., Udoh, F.D. \& Bassey, P.G. 2014. Evaluation of rice husk as fluid loss control additive in waterbased drilling mud. SPE Nigeria Annual International Conference and Exhibition, Society of Petroleum Engineers, 10.

Qiao, B., Liang, Y., Wang, T.-J. \& Jiang, Y. 2016. Surface modification to produce hydrophobic nano-silica particles using sodium dodecyl sulfate as a modifier. Applied Surface Science 364: 103-109.

Ragab, A. M. S. \& Noah, A. 2014. Reduction of formation damage and fluid loss using nano-sized silica drilling fluids. Petroleum Technology Development Journal, 2: 75-88.

Shah, S. N., Shanker, N.H. \& Ogugbue, C.C. 2010. Future challenges of drilling fluids and their rheological measurements. American Association of Drilling Engineers 10: 1-16.

Vryzas, Z. \& Kelessidis, V. C. 2017. Nano-based drilling fluids: A Review. Energies 10: 540. doi:10.3390/ en10040540.

Zamir, A. \& Siddiqui, N. A. 2017. Investigating and enhancing mud cake reduction using smart nano clay based WBM Journal of Petroleum \& Environmental Biotechnology 8: 8-11.

*Rosiah Rohani, Mohd Dzul Khairi Mohd Saparti, Nor Azima Mohd Jali, Ying Tao Chung,

Wan Rosli Wan Sulaiman

Research Centre for Sustainable Process Technology, Chemical Engineering Programme,

Faculty of Engineering and Built Environment, Universiti Kebangsaan Malaysia, 43600 UKM Bangi, Selangor, Malaysia.

*Corresponding author; email: rosiah@ukm.edu.my

Received date: $30^{\text {th }}$ March 2018

Accepted date: $23^{\text {rd }}$ July 2018

Online First date: $1^{\text {st }}$ October 2018

Published date: $30^{\text {th }}$ November 2018 